\title{
Communal farmers' perceptions of tick-borne diseases affecting cattle and investigation of tick control methods practiced in Zimbabwe.
}

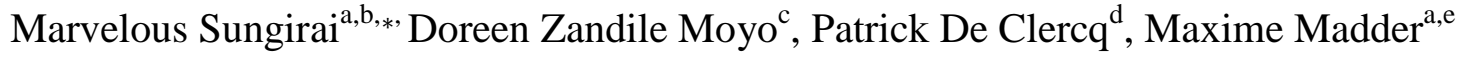 \\ ${ }^{a}$ Department of Biomedical Sciences, Unit of Veterinary Entomology, Institute of Tropical Medicine, \\ Nationalestraat 155, 2000 Antwerp, Belgium \\ ${ }^{\mathrm{b}}$ Department of Livestock and Wildlife Management, Midlands State University, 1 Senga Road, Private Bag \\ 9055, Gweru, Zimbabwe \\ ${ }^{c}$ Department of Biological Sciences, Midlands State University, 1 Senga Road, Private Bag 9055, Gweru, \\ Zimbabwe \\ ${ }^{\mathrm{d}}$ Department of Crop Protection, Ghent University, Coupure Links 653, 9000 Ghent, Belgium \\ ${ }^{\mathrm{e}}$ Department of Veterinary Tropical Diseases, Faculty of Veterinary Science, University of Pretoria, Private Bag \\ X04, Onderstepoort 0110, South Africa
}

\begin{abstract}
Tick borne diseases (TBDs) are responsible for huge economic losses in cattle production in most African countries where the majority of cattle owners are the resource poor communal farmers. Governments have initiated and co-ordinate tick control programs with farmers required to contribute funds for their sustenance. The success of these programs will hinge upon the involvement of communal farmers in their design, implementation and evaluation. To this end, 313 communal farmers (approximately $8.4 \%$ of the target population) were interviewed and 3 focus group discussions were carried out in the southern low-veld part of Zimbabwe with the objectives of investigating communal farmers' perceptions on TBDs affecting cattle, level of participation in government initiated tick control programs, other tick control methods practiced, types of acaricides used and their perceived effectiveness. There was a general awareness of TBDs with $67.7 \%(n=212)$ farmers being able to describe tick diseases with names or clinical and post-mortem signs. The diseases or situations frequently associated with ticks were codwriosis $(38 \%, \mathrm{n}=119)$, mastitis $(36.7 \%, \mathrm{n}=115)$, anaplasmosis $(36.1 \%, \mathrm{n}=113)$, body damage $(28.4 \%, \mathrm{n}=89)$, babesiosis $(24.6 \%, \mathrm{n}=77)$ and poor body condition $(16.6 \%, n=52)$. Cattle mortalities due to TBDs were reported by $23.8 \%(n=74)$ of the farmers. Farmers $(40.6 \%, n=127)$ reported an increase in the number of cases of TBDs while $53.4 \%(n=167)$ did not see an increase. The plunge dip was consistently used by farmers $(70.3 \%, \mathrm{n}=220)$ to control ticks. Other tick control methods practiced were the hand spraying $(67.4 \%, \mathrm{n}=211)$, hand dressing $(16.6 \%, \mathrm{n}=52)$, traditional methods $(5.4 \%, \mathrm{n}=17)$, use of pour-ons $(4.5 \%, \mathrm{n}=14)$ and smearing $(2.2 \%, \mathrm{n}=7)$. The formamidines were the most common class of acaricide used $(59.4 \%, \mathrm{n}=186)$, followed by synthetic pyrethroids $(29.1 \%$, $\mathrm{n}=91)$, macro cyclic lactones $(12.8 \%, \mathrm{n}=40)$ and organophosphates $(4.5 \%, \mathrm{n}=14)$. Most farmers $(75.2 \%, \mathrm{n}=231)$ perceived these acaricides to be effective in controlling ticks. The results of focus group discussions showed that a number of factors influenced the success of government initiated tick control programs and these included inconsistent supply of acaricides, unaffordable dipping fees, lack of water, long distance to the dip tank, lack of
\end{abstract}


information on dipping procedures and lack of knowledge on strategies for delaying acaricide resistance. This study demonstrates that while farmers can be a valuable source of information with regards to the epidemiology of tick borne diseases affecting their cattle, there is still need for further training in understanding the TBDs and strategies for their control.

Key words: participatory, epidemiology, ticks, tick-borne diseases, communal farmers, control.

\section{Introduction}

Ticks and tick-borne diseases (TBDs) are one of the major constraints to livestock production in the (sub) tropical areas of the world (Jongejan and Uilenberg, 2004). Global economic losses due to ticks and tick-borne diseases have been conservatively put at US $\$ 18.7$ billion annually (De Clercq et al., 2012). The losses are incurred through the direct effects of ticks as blood sucking parasites and indirect effects as disease vectors which will lead to reduced growth rate, fertility problems, decline in milk production, reduced value of hides and livestock mortalities, notwithstanding the costs associated with treatment and control (Minjauw and Mcleod, 2003). The best way to control TBDs is through the control of the vector ticks (Willadsen, 2006) and various strategies have been proposed (Jonsson, 2004; Pegram et al., 2000; Peter et al., 2005). Historically, in most countries, particularly in Africa, the control of ticks and other vectors has been the responsibility of veterinary departments financed by the government but this responsibility has been transferred to livestock owners due to economic structural adjustment programs (Peter et al., 2005). However, this development has led to a widening gap between the veterinary services and livestock owners such that veterinarians and other animal health professionals no longer engage farmers to learn about their views, their problems and disease priorities (Mariner et al., 2011).

Since livestock owners are now playing a pivotal role in the control of TBDs, it becomes important to investigate the farmers' perceptions on the constraints they face and the benefits of the different technologies they use to solve those constraints (IFAD, 2004). This could be best achieved by conducting participatory epidemiological surveys where farmers are involved in defining and prioritizing veterinary related problems and also identifying and developing solutions to those problems (Catley et al., 2012). Studies of this nature will lead to more effective management of livestock diseases. This is so because the priorities of the farmers might be different from the priorities of the national veterinary services and they should be taken into account in the implementation of livestock disease control programs (De Garine-Wichatitsky et al., 2013).

The livestock sector in Zimbabwe is composed of large scale commercial, small scale commercial, the A1 and A2 resettlement as well as the communal farmers (Mavedzenge et al., 2006). The large scale, small scale and resettlement farmers are involved in intensive livestock production for profit. The A1 and A2 resettlement farmers are those that have benefited from the land reform program, with the latter farming on a large scale while the 
former are predominantly small scale farmers. Farming in the communal sector is largely for subsistence purposes with occasional selling of surplus in times of emergencies. It is important to note, however, that communal farmers in Zimbabwe own the majority of the cattle at more than $80 \%$ (Tavirimirwa et al., 2013).

Historically the most important tick borne diseases in the country are cowdriosis, babesiosis, anaplasmosis and theileriosis. The epidemiology of these diseases has been studied in the past (Katsande et al., 1999a; Latif et al., 2001; Norval et al., 1984a; Peter et al., 1998). Tick-borne diseases are responsible for more than $60 \%$ of all cattle mortalities in the country (Sungirai et al., 2015). This has led to the government playing a central role in tick control programs in communal areas and A1 resettlement areas, where they co-ordinate the purchase and supply of acaricides. Communal and A1 resettlement farmers are required to pay a fee of USD $\$ 2$ per animal annually so that they participate in these government initiated programs. In large scale, small scale and A2 resettlement schemes it is largely the prerogative of the farmers to take their own initiatives when it comes to tick control.

In communal and A1 resettlement areas tick control is primarily based on the use of the plunge dip where communal farmers who would have paid dipping fees bring their cattle to a centrally located dip tank and have them submerged in a dip wash with acaricides, which is commonly referred to as 'dipping'. The reduction in government financial subsidies in tick control has been seen to change the attitudes and perceptions of farmers with regards to tick control programs (Pegram et al., 1993). It will be important then to understand whether farmers perceive TBDs the way the government does, investigate their level of participation in tick control programs and their own interventions in as far as tick control is concerned. As highlighted earlier, participatory surveys will be helpful in soliciting such kind of information which will be very useful in sustainable disease control programs (Masika et al., 1997).

Communal farmers can have a large wealth of indigenous knowledge on livestock diseases which could be viewed as a natural extension of the veterinary diagnostic service (Catley and Mariner, 2002). Disease control programs often have failed because the local farmers have not been involved in identifying their problems and selecting, testing and evaluating possible solutions (Minjauw et al., 2002). According to (Chenyambuga et al., 2010) the currently held concept of TBDs control has to be revised and should consider the indigenous knowledge of livestock keepers. Literature search on the involvement of farmers in studying the epidemiology of diseases in Zimbabwe revealed that only a few studies had been conducted (Chikerema et al., 2013; De Garine-Wichatitsky et al., 2013; Mosalagae et al., 2011; Pfukenyi et al., 2010) and none of these have directly looked at TBDs. This is despite the importance placed on TBDs by the government Department of Veterinary Services in the country. Hence the purpose of this study was to investigate the perception of communal farmers with regards to TBDs, level of participation in government initiated tick control programs, extent of practicing other tick control methods and classes of acaricides used. The influence of age, gender, level of education, farmer training and problems of TBDs in the area on the awareness of TBDs was also investigated. 


\section{Materials and Methods}

\section{Study area}

The study was carried out in Bikita, a district in Masvingo province of Zimbabwe (Figure 1).There are three distinct ecological regions in the district (Chikodzi et al., 2013). The northwestern part falls under ecological region 3 at an altitude of between 500-1000m above sea level with an average annual rainfall of $650-800 \mathrm{~mm}$. The temperature ranges from $18-24^{\circ} \mathrm{C}$. The south-western, central and north eastern part falls under ecological region 4 and this region dominates most of Bikita district. Average rainfall is $400-640 \mathrm{~mm}$ per year with an altitude above sea level of $450-900 \mathrm{~m}$. Seasonal droughts are common. The temperature ranges from $20-25^{\circ} \mathrm{C}$. The extreme south and south-eastern part falls under ecological region 5. The average annual rainfall is $300-500 \mathrm{~mm}$ with an altitude above sea level of $450 \mathrm{~m}-500 \mathrm{~m}$. The climate is very hot with a mean temperature range of $22-30^{\circ} \mathrm{C}$. Ecological region 5 of Bikita is largely composed of the Save Valley Conservancy with large tracts of forestry and wildlife areas and low cattle densities and or absence of cattle.

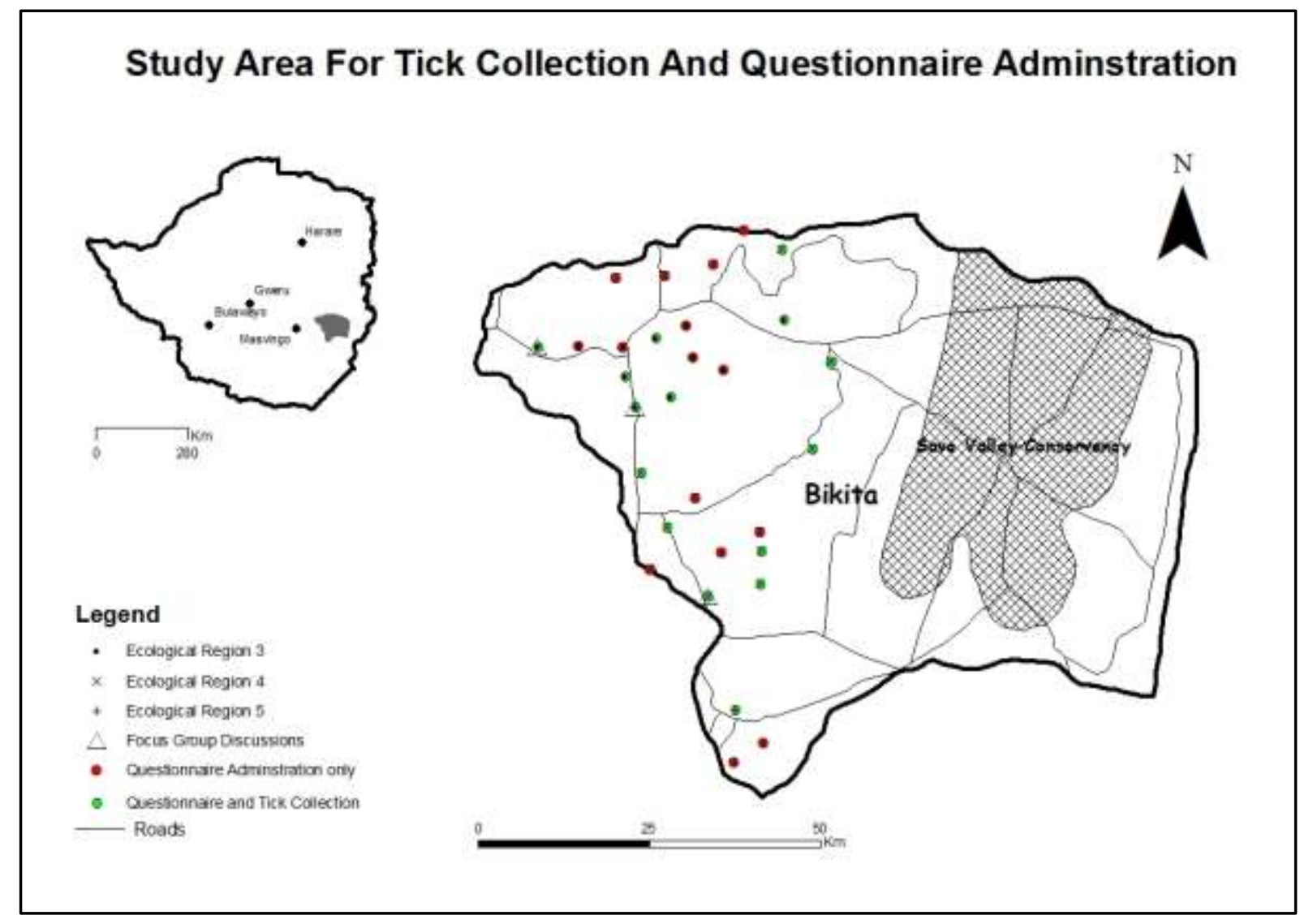

Figure 1: Map showing the areas where ticks were collected and questionnaires were administered

\section{Data collection}

The study was carried out in two phases and was designed to be carried out as personal interviews and focus group discussions. Informal discussions were first carried out with key 
informants in the district on general animal health issues and tick-borne diseases in particular. The key informants included the animal health inspectors, livestock specialists, extension officers, village heads, school teachers. Thereafter a questionnaire was designed and tested amongst veterinary assistants and 30 farmers who were randomly selected in the district. After this initial exercise the questionnaire was re-designed taking into account the inputs and modifications that were identified during the pre-testing stage. The interviewers were selected from local veterinary assistants who were trained in the administration of the questionnaire to solicit information without bias.

The personal interviews were planned such that they occurred on dipping days. It was believed that this was not a significant source of selection bias since most if not all of the communal farmers are expected to bring their cattle to the dip (De Garine-Wichatitsky et al., 2013). Dipping sessions are conducted by a dip attendant who is employed by the government and ensures that dipping procedures are followed. The dip attendant works closely with the local Livestock Development Committee (LDC) which is comprised of selected members of the village who are responsible for ensuring among other things that water is fetched in nearby dams, rivers or wells and put into the dip, and that villagers pay dipping fees. Whenever there are important issues to be discussed by the community this is done during the dipping days as then most farmers would be available. Therefore dipping sessions provide a platform for easy access to cattle owners. Hence for the purposes of this study, the dip attendant together with LDCs were asked to inform farmers of special meetings during dipping days in order to facilitate the conducting of interviews.

The type of information gathered included age, sex, level of education, farmer training, knowledge of ticks and tick-borne diseases, ranking of the most important tick-borne and tick related disease according to the farmer. Farmers were asked if they knew about TBDs, and if they did they were asked to give names of any TBDs they knew or describe clinical or postmortem signs. The name of the disease was only inferred when typical clinical and postmortem signs were observed by the farmers. In the case when atypical clinical and postmortem signs were given, no disease was assigned. Farmers were asked also on the consistency of using the plunge dip: if farmers had last brought their cattle for dipping at the most two weeks before they were regarded as consistent, otherwise if it was more than two weeks they were not considered consistent. The use of other tick control methods practiced apart from the plunge dip was also investigated. Other questions asked included the types of acaricides used (farmers were asked before the meeting to bring sachets of the chemicals they use for tick control if ever they had any), views on acaricide resistance (farmers were asked if they would see any changes in the number of ticks on the animal after application of acaricides), trends of tick-borne diseases over the past 5 years, cattle losses due to tick-borne diseases in the past three months and the person who confirmed the diagnosis in the event of cattle deaths.

\section{Sampling}

Multi-stage sampling was done to select the dip tanks and the farmers to be used in the study. They were 68 operational dip tanks in the area. The dip tanks were first stratified according to 
ecological regions 3, 4 and 5 which led to 9, 18 and 4 dip tanks being randomly selected within each ecological region, respectively. Thus 31 diptanks were selected for the study. According to the law every cattle owner is supposed to have a stock card which shows the number of cattle he or she owns, thus in a household there can be more than one cattle owner. There were 15114 cattle owners in the area during the time of the survey of which 8120 were found in the 31dip tanks selected for the study. There were approximately 3720 households with stock card holders in the study dip tanks. Each diptank had between 100 and 150 households with stock card holders. At the dip tank level, the household with a stock card holder was the sampling unit. A list of stock card holders was obtained from the veterinary department office to get a sampling frame for the study and at the dip tank the stock card holders were placed in their household so as not to choose more than one stock card holder per household. At least ten households with stock card holders were randomly selected at each dip tank. A total of 313 household representatives with stock card holders were interviewed in this study.

\section{Focus group discussions}

Focus group discussions were conducted at 3 dip tanks ( 2 and 1 dip tanks in ecological region 3 and 4, respectively) which were randomly selected from the 31 dip tanks initially chosen for the study. This was done to make independent observations on the dipping process, discuss with key informants and members of the LDCs on their approach towards tick control, role of government extension services in disease control, problems faced and possible solutions to those problems.

\section{Tick collection}

Ticks were collected on 47 cattle (at least 2 cattle per dip tank) with heavy infestations. This was done in 16 out of the 31 randomly selected dip tanks $(6,9$ and 1 dip-tanks in ecological regions 3, 4 and 5, respectively). Whole body collections were made taking into account the predilection sites ensuring collection of all the tick species on the animal. The ticks were identified using taxonomic keys (Walker et al., 2003) with the aid of a Zeiss stereo microscope at x80 magnification. Rhipicephalus microplus identification was confirmed by PCR-RFLP using the protocol of Lempereur et al., (2010).

\section{Data analysis}

Information gathered from the questionnaire was collated and entered into SPSS version 21 for descriptive and statistical analysis. Not all the farmers were able to name the disease but some did give clinical or post mortem signs. The pattern of signs given by the farmers was observed and this was put into coherent categories such as, "bloody urine, hard dung, teat damage, swollen udder, nervous symptoms in the case of farmers saying cows appeared mad, emaciation," etc. When the signs given were typical of a TBD or any other disease, signs were attributed to that disease e.g., "heartwater signs". However, when the signs were atypical no name was assigned for a disease and the description was e.g., "loss of appetite". 
The non-parametric Friedman test was used to rank the most common diseases mentioned by farmers. Scores were given for the diseases as they had been listed by farmers. A score of 1 was given to the disease first on the list whilst diseases furthest from the list were given higher scores. The chi-square test was used to determine the significance of associations between the knowledge of TBDs as well as use of other tick control methods with demographic factors (sex, age, level of education and basic farmer training) together with variables such as problems of TBDs in the area and claim of knowledge of TBDs. All statistical tests were done at the $5 \%$ level of significance.

Data from focus group discussions was collated and synthesized.

\section{Results}

\section{Demographics and summary of major responses}

The demographics of the population under study are shown in Table 1. More males were interviewed as compared to females. Most respondents were above the age of 40. The majority of the people had attended basic education with a low number admitting to never have gone to school. Most of the farmers interviewed had not participated in basic farmer training.

Furthermore, Table 1 shows the responses of farmers to various questions asked during the study. The majority of the farmers reported problems of ticks and tick-borne / related diseases. Most farmers were consistently following the dipping regime recommended by the Department of Veterinary Services. In addition to that they also practiced other tick control methods with hand spray by a knapsack being the most commonly used method. Of the acaricides used, the formamidine group was the most common while the organophosphates were the least common. A large proportion of farmers viewed these acaricides as being effective in controlling ticks. Few farmers had lost cattle due to tick-borne / related problems in the previous 3 months. Of those that lost cattle to TBDs the majority of the diagnosis was confirmed by local veterinary officers while in some cases farmers did their own diagnosis or relied on colleagues. There were mixed responses as to whether TBDs were increasing in the district although a large proportion were of the view that the incidence of the diseases was increasing. 
Table 1: Demographics and summary of major responses

\begin{tabular}{|c|c|c|c|c|}
\hline Factor & Level & Respondents (\%) & $\begin{array}{l}\text { Lower limit 95\% Confidence } \\
\text { Interval/\% }\end{array}$ & $\begin{array}{l}\text { Upper limit 95\% Confidence } \\
\text { Interval } / \%\end{array}$ \\
\hline \multirow[t]{2}{*}{ Gender } & Male & $64.6(197 / 305)$ & 59.23 & 69.97 \\
\hline & Female & $35.4(108 / 305)$ & 30.03 & 40.77 \\
\hline \multirow[t]{4}{*}{ Age } & $18-25$ & $9(28 / 312)$ & 5.82 & 12.18 \\
\hline & $26-30$ & $11.5(36 / 312)$ & 7.96 & 15.04 \\
\hline & $31-40$ & $26(81 / 312)$ & 21.13 & 30.87 \\
\hline & +40 & $53.5(168 / 312)$ & 47.97 & 59.03 \\
\hline \multirow[t]{8}{*}{ Level of education } & Primary & $30.1(94 / 312)$ & 25.02 & 35.18 \\
\hline & Secondary & $43.6(136 / 312)$ & 38.11 & 49.09 \\
\hline & Advanced Level & $4.2(13 / 312)$ & 1.98 & 6.42 \\
\hline & Certificate (1 year of study) & $6.1(19 / 312)$ & 3.45 & 8.75 \\
\hline & Diploma (3 years of study) & $4.2(13 / 312)$ & 1.98 & 6.42 \\
\hline & Bachelors & $2.9(9 / 312)$ & 1.04 & 4.76 \\
\hline & Post-Bachelors (Masters) & $1(3 / 312)$ & -0.10 & 2.10 \\
\hline & None & $8.3(26 / 312)$ & 4.99 & 11.01 \\
\hline \multirow[t]{2}{*}{ Basic farmer training course } & Yes & $39.7(124 / 312)$ & 34.28 & 45.12 \\
\hline & No & $60.3(188 / 312)$ & 54.88 & 65.72 \\
\hline \multirow[t]{2}{*}{ Problem with ticks and TBDs } & Yes & $86.6(271 / 313)$ & 82.83 & 90.37 \\
\hline & No & $13.4(142 / 313)$ & 9.63 & 17.17 \\
\hline \multirow{2}{*}{$\begin{array}{l}\text { Claim of knowledge of ticks } \\
\text { and TBDs }\end{array}$} & Yes & $71.3(219 / 307)$ & 66.28 & 76.39 \\
\hline & No & $28.7(88 / 307)$ & 23.61 & 33.72 \\
\hline \multirow[t]{4}{*}{ Last time dipping done } & One week ago & $22.7(71 / 313)$ & 18.06 & 27.34 \\
\hline & Two weeks ago & $47.6(149 / 313)$ & 42.07 & 53.13 \\
\hline & One month ago & $19.5(61 / 313)$ & 15.11 & 23.89 \\
\hline & More than a month ago & $10.2(32 / 313)$ & 6.85 & 13.55 \\
\hline \multirow{2}{*}{$\begin{array}{l}\text { Alternative tick control } \\
\text { methods }\end{array}$} & Yes & $79.6(249 / 313)$ & 75.14 & 84.06 \\
\hline & No & $20.4(64 / 313)$ & 15.94 & 24.86 \\
\hline \multirow[t]{5}{*}{ Tick control methods } & Pour on & $4.5(14 / 313)$ & 2.20 & 6.80 \\
\hline & Hand spray (Knapsack) & $67.4(211 / 313)$ & 62.21 & 72.59 \\
\hline & Smear (Tick grease) & $2.2(7 / 313)$ & 0.57 & 3.83 \\
\hline & Traditional methods & $5.4(17 / 313)$ & 2.90 & 7.90 \\
\hline & Hand dressing & $16.6(52 / 313)$ & 12.48 & 20.72 \\
\hline \multirow[t]{4}{*}{ Type of acaricide used } & Formamidines & $59.4(186 / 313)$ & 53.96 & 64.84 \\
\hline & Synthetic pyrethroids & $29.1(91 / 313)$ & 24.07 & 34.13 \\
\hline & Organophosphates & $4.5(14 / 313)$ & 2.20 & 6.80 \\
\hline & Macro-cyclic lactones & $12.8(40 / 313)$ & 9.10 & 16.50 \\
\hline \multirow{3}{*}{$\begin{array}{l}\text { Effectiveness of acaricides } \\
\text { (viewed by the } \\
\text { presence/absence of high tick } \\
\text { loads after application of } \\
\text { acaricide) }\end{array}$} & Yes & $75.2(231 / 313)$ & 70.63 & 80.17 \\
\hline & No & $17.3(53 / 313)$ & 11.13 & 19.07 \\
\hline & No idea & $9.5(29 / 313)$ & 6.25 & 12.75 \\
\hline \multirow{2}{*}{$\begin{array}{l}\text { Loss of cattle due to ticks in } \\
\text { past } 3 \text { months }\end{array}$} & Yes & $23.8(74 / 311)$ & 19.07 & 28.53 \\
\hline & No & $76.2(237 / 311)$ & 71.47 & 80.93 \\
\hline \multirow{4}{*}{$\begin{array}{l}\text { Confirmation of diagnosis } \\
\text { when cattle had died } \\
\text { (directed at those who had } \\
\text { lost cattle due to ticks) }\end{array}$} & Self & $14.3(42 / 313)$ & 10.42 & 18.18 \\
\hline & Veterinary Officer & $18.4(54 / 313)$ & 14.11 & 22.69 \\
\hline & Colleagues & $9.6(28 / 313)$ & 6.34 & 12.86 \\
\hline & No response & $60.3(189 / 313)$ & 54.88 & 65.72 \\
\hline \multirow[t]{3}{*}{ View of ticks in past 5 years } & No increase & $53.4(167 / 313)$ & 47.87 & 58.93 \\
\hline & Increase & $40.6(127 / 313)$ & 35.16 & 46.04 \\
\hline & I don't know & $6.1(19 / 313)$ & 3.45 & 8.75 \\
\hline
\end{tabular}




\section{Perception of ticks, tick-borne and related diseases by communal farmers}

A total of $71.3 \%$ (219/307) farmers claimed to have knowledge of TBDs, of these $74.4 \%$ (163/219) gave the actual names of the diseases and 22.4\% (49/219) related TBDs with clinical / post-mortem signs. A total of 40 different classifications were related to TBDs by farmers and these included diseases, clinical and post-mortem signs. If these followed similar patterns, they were grouped and 30 different classifications were used for analysis by the Friedman test. The results of the frequency of mention and ranking are shown in Table 2 . According to farmers, cowdriosis, mastitis, anaplasmosis, body damage, babesiosis and poor body condition were the most frequently mentioned effects of ticks on cattle. Some farmers managed to describe TBDs' clinical or post-mortem signs and the most common frequently mentioned were "animal moving in circles, water in chest cavity, red urine and hard dung". Direct effects of ticks on cattle were frequently highlighted by farmers and these were, general body damage with tick wounds on most parts of the animal, udder and teat damage, ear damage and abscesses. 
Table 2: Farmers' views on effects of ticks on cattle ( diseases and clinical / post-mortem signs)

\begin{tabular}{|c|c|c|c|c|}
\hline & $\begin{array}{l}\text { Frequency of } \\
\text { mention } \\
\text { (expressed as } \\
\text { percent of total } \\
\text { respondents, } \\
\mathrm{n}=313 \text { ) }\end{array}$ & $\begin{array}{l}\text { Lower } \\
\text { limit } 95 \% \\
\text { confidence } \\
\text { Interval/\% }\end{array}$ & $\begin{array}{l}\text { Upper } \\
\text { limit } 95 \% \\
\text { confidence } \\
\text { Interval/\% }\end{array}$ & Mean rank score (Friedman test) \\
\hline Heartwater (Cowdriosis) & $38(\mathrm{n}=119)$ & 32.62 & 43.38 & 11.15 \\
\hline Mastitis & $36.7(n=115)$ & 31.36 & 42.04 & 11.17 \\
\hline Gall sickness (Anaplasmosis) & $36.1(n=113)$ & 30.78 & 41.42 & 11.53 \\
\hline Body damage (general) & $28.4(n=89)$ & 23.40 & 33.40 & 12.50 \\
\hline Red water (Babesiosis) & $24.6(n=77)$ & 19.83 & 29.37 & 13.19 \\
\hline Poor body condition & $16.6(\mathrm{n}=52)$ & 12.48 & 20.72 & 14.35 \\
\hline $\begin{array}{l}\text { Mastitis signs (swollen udder, } \\
\text { decline / cessation of milk) }\end{array}$ & $14.4(n=45)$ & 10.51 & 18.29 & 14.63 \\
\hline Ear damage & $8.6(n=30)$ & 5.49 & 11.71 & 15.47 \\
\hline $\begin{array}{l}\text { Heartwater signs (groaning, animal } \\
\text { moving in circles, water in chest } \\
\text { cavity(post-mortem), twitching of } \\
\text { eyes) }\end{array}$ & $8.9(n=28)$ & 5.75 & 12.05 & 15.49 \\
\hline Red water signs (red urine) & $8(n=25)$ & 4.99 & 11.01 & 15.73 \\
\hline Abscesses & $7(n=22)$ & 4.17 & 9.83 & 15.81 \\
\hline Udder teat damage & $5.8(n=18)$ & 3.21 & 8.39 & 15.93 \\
\hline Gall sickness signs (hard dung) & $5.4(n=17)$ & 2.90 & 7.90 & 16.02 \\
\hline January disease (Theileriosis) & $5.1(n=16)$ & 2.66 & 7.54 & 16.13 \\
\hline Sweating sickness & $4.2(n=13)$ & 1.98 & 6.42 & 16.22 \\
\hline Loss of appetite salivation & $2.9(n=9)$ & 1.04 & 4.76 & 16.42 \\
\hline Foot rot & $2.6(n=8)$ & 0.84 & 4.36 & 16.47 \\
\hline Joint ill & $2.6(n=8)$ & 0.84 & 4.36 & 16.47 \\
\hline $\begin{array}{l}\text { Sweating sickness signs (hair loss in } \\
\text { calves) }\end{array}$ & $2.2(\mathrm{n}=7)$ & 0.57 & 3.83 & 16.51 \\
\hline Loss of appetite & $2.2(\mathrm{n}=7)$ & 0.57 & 3.83 & 16.52 \\
\hline $\begin{array}{l}\text { Large and small swollen lumps in } \\
\text { body }\end{array}$ & $1.9(n=6)$ & 0.39 & 3.41 & 16.53 \\
\hline $\begin{array}{l}\text { January disease signs (swollen lumps } \\
\text { on neck) }\end{array}$ & $1.3(n=4)$ & 0.05 & 2.55 & 16.63 \\
\hline $\begin{array}{l}\text { Foot rot signs (sores in inter-digital } \\
\text { spaces) }\end{array}$ & $0.6(n=2)$ & -0.26 & 1.46 & 16.74 \\
\hline Blindness & $0.6(n=2)$ & -0.26 & 1.46 & 16.74 \\
\hline Blood stained dung & $0.6(n=2)$ & -0.26 & 1.46 & 16.75 \\
\hline Swollen joints & $0.6(n=2)$ & -0.26 & 1.46 & 16.75 \\
\hline Salivation & $0.3(n=1)$ & -0.31 & 0.91 & 16.79 \\
\hline Dyspnea & $0.3(n=1)$ & -0.31 & 0.91 & 16.79 \\
\hline Loss of appetite and groaning & $0.3(n=1)$ & -0.31 & 0.91 & 16.79 \\
\hline Lumpy skin disease & $0.3(n=1)$ & -0.31 & 0.91 & 16.80 \\
\hline
\end{tabular}




\section{Factors influencing knowledge of TBDs and use of other tick control methods}

Table 3 shows the factors influencing knowledge of TBDs and use of other tick control methods. The ability of the farmers to name a TBD was influenced by level of education, participation in a farmer training course, problems of TBDs in the area and claim of knowledge of TBDs affecting cattle in the area. The ability to name TBDs increased with improved level of education, attendance at a farmer training course, increased problems of TBDs in the area. Farmers who claimed knowledge of TBDs were able to name the TBDs affecting cattle while a low proportion of farmers who claimed no knowledge of TBDs went on to list these as TBDs.

More males were able to describe the signs of TBDs as compared with females while those who claimed to have knowledge of TBDs managed to describe the signs. Surprisingly a few of the farmers who claimed no knowledge of TBDs were able to describe the signs of TBDs. The use of other tick control methods was significantly influenced by farmer sex, attendance at a farmer training course and claim of knowledge of TBDs.

Table 3: Factors influencing knowledge of TBDs, and use of other tick control methods

\begin{tabular}{|c|c|c|c|c|}
\hline Factor & Level & $\begin{array}{l}\begin{array}{l}\text { Ability } \\
(\%=y e s)\end{array} \\
\text { to name }\end{array}$ & $\begin{array}{l}\text { Ability to describe } \text { TBD } \\
\text { signs }(\%=\text { =yes })\end{array}$ & $\begin{array}{l}\text { Use of other tick control } \\
\text { methods }(\%=y e s)\end{array}$ \\
\hline \multirow[t]{5}{*}{ Age } & $18-25$ & $\begin{array}{ll}60.7 & (17 / 28)\end{array}$ & $(1 / 28)$ & $\begin{array}{ll}78.6 & (22 / 28)\end{array}$ \\
\hline & $26-30$ & $63.9 \quad(23 / 36)$ & $(5 / 36)$ & $83.6 \quad(30 / 36)$ \\
\hline & $31-40$ & $51.9 \quad(42 / 81)$ & $(12 / 81)$ & $76.5 \quad(62 / 81)$ \\
\hline & +40 & $55.1 \quad(92 / 167)$ & $22.8 \quad(38 / 167)$ & $80.2 \quad(134 / 167)$ \\
\hline & & $\chi^{2}=1.775, p=0.620$ & $\chi^{2}=7.492, p=0.058$ & $\chi^{2}=0.83, p=0.842$ \\
\hline \multirow{3}{*}{ Gender } & male & $(112 / 197)$ & $(45 / 197)$ & $83.2(164 / 197)$ \\
\hline & female & $(58 / 108)$ & $10.2 \quad(11 / 108)$ & $73.1(79 / 108)$ \\
\hline & & $\chi^{2}=0.280, p=0.596$ & $\chi^{2}=7.456, p=0.006^{* *}$ & $\chi^{2}=4.394, p=0.036^{*}$ \\
\hline \multirow[t]{9}{*}{ Level of education } & Primary & $(45 / 194)$ & $22.3 \quad(21 / 94)$ & $77.7(73 / 94)$ \\
\hline & Secondary & $53.7 \quad(73 / 136)$ & $19.1 \quad(26 / 136)$ & $78.7(107 / 136)$ \\
\hline & Advanced level & $61.5 \quad(8 / 13)$ & $15.4 \quad(2 / 13)$ & $84.6(11 / 13)$ \\
\hline & Certificate & $94.7 \quad(18 / 19)$ & $(0 / 19)$ & $78.9(15 / 19)$ \\
\hline & Diploma & $69.2 \quad(9 / 13)$ & $23.1 \quad(3 / 13)$ & $100(13 / 13)$ \\
\hline & Degree & $(9 / 9)$ & $11.1 \quad(1 / 9)$ & $100(9 / 9)$ \\
\hline & Post-graduate (masters) & $(2 / 3)$ & $33.3 \quad(1 / 3)$ & $100(3 / 3)$ \\
\hline & None & $(10 / 25)$ & $8 \quad(2 / 25)$ & $68 \quad(17 / 25)$ \\
\hline & & $\chi^{2}=25.247, \mathrm{p}=0.001 * * *$ & $\chi^{2}=8.252, p=0.311$ & $\chi^{2}=8.935, p=0.257$ \\
\hline \multirow[t]{3}{*}{ Basic farmer training course } & yes & $69.4 \quad(86 / 124)$ & $17.7(22 / 124)$ & $85.5(106 / 124)$ \\
\hline & no & $46.8 \quad(88 / 188)$ & $18.1(34 / 188)$ & $76.1(143 / 188)$ \\
\hline & & $\chi^{2}=15.398, \mathrm{p}<0.0001 * * *$ & $\chi^{2}=0.006, p=0.938$ & $\chi^{2}=4.114, p=0.043^{*}$ \\
\hline \multirow{3}{*}{$\begin{array}{l}\text { Problems of ticks and tick } \\
\text { borne diseases }\end{array}$} & yes & $60.9 \quad(165 / 271)$ & $19.2 \quad(52 / 271)$ & $80.4(218 / 271)$ \\
\hline & no & $21.4 \quad(9 / 42)$ & $9.5 \quad(4 / 42)$ & $73.8(31 / 42)$ \\
\hline & & $\chi^{2}=22.932, \mathrm{p}<0.0001 * * *$ & $\chi^{2}=2.312, p=0.128$ & $\chi^{2}=0.984, p=0.321$ \\
\hline \multirow[t]{3}{*}{ Knowledge of TBDs } & yes & $74.4 \quad(163 / 219)$ & $22.4(49 / 219)$ & $84 \quad(184 / 219)$ \\
\hline & no & $(8 / 88)$ & $8 \quad(7 / 88)$ & $70.5(62 / 88)$ \\
\hline & & $\chi^{2}=108.609, \mathrm{p}<0.0001 * * *$ & $\chi^{2}=8.752, \mathrm{p}=0.003^{* * *}$ & $\chi^{2}=7.254, p=0.007 * *$ \\
\hline
\end{tabular}




\section{Tick collection results}

Seven Ixodidae tick species were identified. The predominant tick species were Amblyomma hebraeum followed by Rhipicephalus decoloratus and Rhipicephalus microplus. Other tick species collected were Hyalomma truncatum, Hyalomma rufipes, Rhipicephalus appendiculatus and Rhipicephalus evertsi evertsi. Table 3 shows the tick collections, dip tank prevalence and mean tick burden per animal. Rhipicephalus microplus dominated in 3 of the dip tanks while $R$. decoloratus dominated in 10 of the dip tanks. In the 4 dip tanks where $R$. microplus occurred it was the only species of the $R$. (Boophilus) ticks collected, whilst the two species co-existed in 5 dip tanks with $R$. decoloratus dominating in 4 dip tanks and $R$. microplus dominating in 1 . Four $R$. microplus ticks obtained from the 4 different dip tanks in the district were confirmed as such by PCR-RFLP.

Table 4: Dip tank prevalence of Ixodidae ticks collected and mean tick burden per animal

\begin{tabular}{|c|c|c|c|c|}
\hline \multirow{2}{*}{ Tick species } & \multirow{2}{*}{$\begin{array}{l}\text { Dip tank prevalence } \\
\text { (Total number of dip } \\
\quad \text { tanks, } n=16 \text { ) }\end{array}$} & \multicolumn{2}{|c|}{$\begin{array}{l}\text { 95\% Confidence Intervals for dip-tank } \\
\text { prevalence }\end{array}$} & \multirow{2}{*}{$\begin{array}{c}\text { Mean tick burden per } \\
\text { animal } \pm \text { standard } \\
\text { error }\end{array}$} \\
\hline & & Lower limit & Upper limit & \\
\hline Amblyomma hebraeum & $94(n=15)$ & 82.36 & 105.64 & $12.72 \pm 2.36$ \\
\hline Hyalomma rufipes & $44(\mathrm{n}=7)$ & 19.68 & 68.32 & $4.14 \quad \pm 5.85$ \\
\hline Hyalomma truncatum & $19(\mathrm{n}=3)$ & -0.22 & 38.22 & $6.00 \quad \pm 5.85$ \\
\hline Rhipicephalus appendiculatus & $31(\mathrm{n}=5)$ & 8.34 & 53.66 & $9.80 \pm 6.92$ \\
\hline Rhipicephalus decoloratus & $63(\mathrm{n}=10)$ & 39.34 & 86.66 & $19.63 \pm 3.55$ \\
\hline Rhipicephalus evertsi evertsi & $56(n=9)$ & 31.68 & 80.32 & $4.88 \pm 3.75$ \\
\hline Rhipicephalus microplus & $50(\mathrm{n}=8)$ & 25.50 & 74.50 & $19.18 \pm 4.67$ \\
\hline
\end{tabular}

\section{Discussion}

This study has demonstrated that centralized dipping programs can be useful in collecting information from farmers which is essential in the management and control of livestock diseases. However, the non-participation of some farmers in surveys conducted on dip days can introduce selection bias which may have influenced the survey results. In this study most farmers were following a consistent dipping program subsidized by the government. As noted by Masika et al. (1997), dipping services are a successful government intervention in the communal livestock production system. In cases where farmers had not dipped their animals for more than a month, it was related to the delay of acaricide supply by the Department of Veterinary Services. Due to inconsistent cash inflows which are also caused by the fact that the farmers are reluctant to pay dipping levies, the government cannot supply acaricides in time, hence tick control might be affected. It was noted that farmers with large herds were 
having challenges to pay dipping levies for all their cattle and hence not all of them were dipping. Focus group discussions also highlighted factors such as water availability and distance to the dip tank as hindering total participation in dipping programs. Dip tanks should ideally be located close to a water source but some-times this is not the case. It is the responsibility of farmers to fill up the tank with water and they do take turns to do this. However, at some dip tanks disagreements arise as to who will fill up the dip tank and such quarrels may result in water not being avail-able at the dip tank. This normally interrupts dipping programs. In addition, some farmers stay more than $10 \mathrm{~km}$ from a dip tank and they have to walk long distances to dip their animals. The majority of these cattle owners are old people who are reluctant to walk such long distances and hence for such farmers, dipping is also done during school holidays when school going children takeover that job. It will be important to further explore the factors that lead to non-participation of farmers in government dipping programs. It was important to note that communal farmers related ticks with a number of effects on livestock. The most common were heartwater (cowdriosis) followed by mastitis, gall sickness(anaplasmosis), tick bite wounds, red water (babesiosis) and poor body condition. Clinical and post-mortem signs which are synonymous with TBDs such as red urine (babesiosis), circling movements of cattle (cowdriosis), hard dung (anaplasmosis), hair loss (sweating sickness) and swollen lumps on the neck (theileriosis) were highlighted by farmers as being caused by ticks. This could have been due to the strong significant association between problem of ticks and ability to name disease. Farmers who had highlighted that TBDs were a problem in the region could either name the disease or describe the signs or symptoms. Munyeme et al., (2010) also found a strong correlation between high prevalence and awareness of a disease. However, farmers incorrectly associated mastitis, joint ill and foot rot as TBDs. Despite these anomalies, farmers seemed to be aware of the major TBDs affecting livestock in the area. This corroborates with the findings of Chatikobo et al., (2013) and De Garine-Wichatitsky et al., (2013) who observed increased farmer knowledge on the diseases affecting livestock.

The southern low-veld part of Zimbabwe is known to be endemic to heartwater and is characterized by the large presence of the vector tick Amblyomma hebraeum (Peter et al., 1999). In this study the prevalence of Amblyomma hebraeum ticks was very high being found in almost all the dip tanks. The predilection sites of the Amblyomma ticks are the perineum and inguinal regions where the udders of female cows are located. The greatest numbers of Amblyomma ticks are usually found on the udder and their bites would leave wounds which become passages of entry for the bacteria that cause mastitis (Moyo and Masika, 2009). This could probably explain why most farmers attributed mastitis to ticks. During focal group discussions farmers highlighted that in some cases calves died due to failure to suckle because of teat damage caused by ticks. These sentiments are in agreement with findings of Hlatshwayo and Mbati (2005), Masika et al., (1997) and Ndhlovu et al., (2009).

The rickettsial parasites that cause anaplasmosis, Anaplasma marginale and Anaplasma centrale, are biologically transmitted largely by the vectors $R$. decoloratus, $R$. evertsi evertsi and $R$. microplus (Norval et al., 1984b). Anaplasmosis can also be transmitted mechanically through biting insects and use of surgical instruments, and transmission by Hyalomma rufipes 
is also possible (Rikhotso et al., 2005). On the other hand, the protozoal parasites that cause babesiosis, Babesia bovis and Babesia bigemina, are biologically transmitted by the ticks $R$. microplus and $R$. decoloratus, with the latter only transmitting B. bigemina (Mason and Norval, 1980). This could explain the higher ranking of anaplasmosis than babesiosis. Theileriosis was only reported to be a problem by farmers close to the wildlife conservancy where buffaloes (Syncerus caffer) are in close contact with domestic livestock. The same observations have also been reported by De Garine-Wichatitsky et al., (2013). In areas far away from the conservancy it was not reported to be a problem by the farmers. This could be due to the low incidence of the vector tick $R$. appendiculatus in the area which is responsible for the transmission of theileriosis.

Sweating sickness and foot rot were other diseases that farmers associated with ticks. Sweating sickness is a tick-borne disease caused by the release of a toxin by the bont-legged tick $H$. truncatum (Mans et al., 2008). Tick collections indicated the presence of $H$. truncatum in the district and as such incidences of sweating sickness would be expected especially in young calves. However, the prevalence of $H$. truncatum appeared to be low in the district, hence the number of times it was mentioned was also low. Farmers could have associated foot rot with ticks since tick species like the Hyalomma spp. can occupy the interdigital clefts and fetlocks of the animals and cause injuries on the hooves of the animal, thereby predisposing them to foot rot and lameness (Apanaskevich and Horak, 2008).

Most farmers practiced other tick control methods apart from the regular dipping conducted through the Department of Veterinary Services and hand spraying by the use of a knapsack was the most common method used by the farmers. Observations indicated that tobacco farming was commonly practiced in the area and the knapsacks that the farmers used to spray their tobacco crop were also used to apply acaricides on their cattle. The formamidines were the common acaricide used by farmers and the Department of Veterinary Services. Other acaricides are less common largely because they are more expensive. Furthermore, amitraz is generally viewed as an effective acaricide by farmers (Mugambi et al., 2012). It is also important to note that some farmers used traditional methods of controlling ticks. In this study, the most common traditional way of controlling ticks was the use of black soot mixed with chillies, which is referred to as chin'ai in the local Shona language. This substance is ground to a fine consistence and $500 \mathrm{~g}$ of the mixture is diluted in 10 litres of water, shaken thoroughly and applied on the body of the animal using a broom or tree branch with fine leaves. The efficacy of this method has not been proven scientifically but the farmers suggested that it was effective. The use of traditional methods in controlling ticks is frequently practiced by resource poor communal farmers (Hlatshwayo and Mbati, 2005; Mugambi et al., 2012).

In this study there was a notable presence of $R$. microplus which is a humid pan-tropical blue tick (Madder et al., 2010) and was not expected in the pre-dominantly dry regions of Bikita district. The presence of $R$. microplus in dry regions has been reported elsewhere in West Africa (Madder et al., 2007), South Africa (Nyangiwe et al., 2013a; Tonnesen et al., 2004), Zambia (Berkvens et al., 1998), East Africa (Lynen et al., 2008) and more recently in Namibia (Nyangiwe et al., 2013b). However, what is noteworthy is the spread of this tick into 
the interior of the country. Preliminary investigations could attribute this to movement of livestock as interviews with the veterinary personnel indicated that farmers in Bikita district are purchasing heavy framed cattle from the eastern parts of the country, particularly in Chipinge, in order to genetically improve their breeds and fetch high prices at the cattle markets. Chipinge is the traditionally known focal area of $R$. microplus in Zimbabwe (Katsande et al., 1999b; Katsande et al., 1996; Mason and Norval, 1980; Smeenk et al., 2000), so this movement of cattle could have led to the movement of the tick in the area. The presence of $R$. microplus in an area is a threat to livestock production because of its invasive character, acaricide resistance and the fact that it transmits the most pathogenic form of bovine babesiosis (Madder et al., 2012). Preliminary discussions with veterinary assistants who have knowledge on livestock diseases did indicate that in some areas within the district, cases of bovine babesiosis were on the increase.

This study has also revealed the need to conduct basic farmer training courses since it was noted that this training had a significant effect on the ability to name disease as well as use of other tick control methods. It has been reported by other researchers that the extension system for livestock production in communal areas is very weak (Chatikobo et al., 2013; Mutibvu et al., 2012). Only a small proportion of farmers indicated that they had undergone basic farmer training and the majority of these were older than 40 years. This group of people could have been trained before the economic meltdown which hit the country and has adversely affected extension services. As a consequence, the majority of the people had not received this training, particularly the younger age classes. The farmers who had undergone training were more aware of TBDs and other tick control methods as compared to the farmers who had not undergone training. The importance of training hence cannot be over emphasized (Peter et al., 2005). Lack of farmer training is one of the constraints in developing farmer managed cost effective tick control programs (Masika et al., 1997). Sex had an effect on the knowledge of TBDs and use of other tick control methods. This could be related to the fact that in most cases males are the keepers of large livestock in communal areas and as such they would be aware of the diseases that affect their livestock. Further, more males had undergone basic farmer training as compared to their female counterparts.

Information gathered from the farmers has indicated that the acaricides being used are effective against ticks. No detailed information exists at the moment with regard to acaricide resistance issues on the major tick species parasitizing livestock in Zimbabwe. However, some farmers did complain of acaricide resistance issues. Acaricide resistance is not only a function of the frequency of acaricide use but of a whole lot of management factors which involve misuse (Adakal et al., 2013; Foil et al., 2004). In one of the dip tanks it was observed that several factors could lead to a reduced efficacy of acaricide treatments. For example due to quarrels farmers do not agree on who is to empty the dip tank and as such the dip becomes heavily silted and the acaricide would sediment at the bottom of the dip. This was observed at one of the dip tanks which had not been replenished with water for close to 12 months. Furthermore, when dipping commences a group of 20-30 animals are required to get into the dip and mix the acaricide with water. This procedure was not followed by the dip attendants and upon interviewing one of the attendants he did not know the volume of the dip as well as 
the mixing ratios of water and the acaricide. Incorrect concentration of acaricides is one of the prime reasons for tick control failure at communal dip tanks (Jonsson, 1997).

\section{Conclusion}

The study indicates that farmers consider ticks and tick-borne diseases a problem in this part of Zimbabwe. Most farmers are aware of the problems caused by ticks and are taking precautionary measures by regularly dipping their livestock. The most common acaricide in use both by the Department of Veterinary Services and the communal farmers is amitraz. This could result in acaricide resistance and to delay resistance development, farmers are encouraged to rotate acaricides for the control of ticks in the area. Furthermore, the presence of $R$. microplus in the Bikita district is of special mention: as the tick has not been recorded in the area, there is need for continued surveillance to monitor the dynamics of the tick in the district. There is also need to target the young age classes less than 40 years of age as well as women when conducting basic farmer training, as it has been revealed that most of them have not undergone the training.

\section{Acknowledgements}

The authors are grateful to the Belgium Department of Development Co-operation (DGD), for the financial assistance rendered for this study to be successful. The staff of the Department of Veterinary Services in Bikita district are acknowledged for their co-operation and assistance in data collection in this study. Mr. B.T. Mudereri in the department of Livestock and Wildlife Management at Midlands State University is greatly acknowledged for help in drawing the maps showing the study area.

\section{Conflict of Interest}

The authors declare that there is no conflict of interest in this study

\section{Reference List}

Adakal, H., Stachurski, F., Chevillon, C., 2013. Tick control practices in Burkina Faso and acaricide resistance survey in Rhipicephalus (Boophilus) geigyi (Acari: Ixodidae). Exp. Appl. Acarol. $59,483-491$.

Apanaskevich, D.A., Horak, I.G., 2008. The genus Hyalomma. VI. Systematics of H. (Euhyalomma) truncatum and the closely related species, $H$. (E.) albiparmatum and $H$. (E.) nitidum (Acari: Ixodidae). Exp. Appl. Acarol. 44, 115-136. 
Berkvens, D.L., Geysen, D.M., Chaka, G., Madder, M., Brandt, J.R., 1998. A survey of the ixodid ticks parasitising cattle in the Eastern province of Zambia. Med Vet. Entomol. 12, 234-240.

Catley, A., Mariner, J., 2002. Where there is no data: Participatory approaches to veterinary epidemiology in pastoral areas of the Horn of Africa. In: International Institute for Environment and Development, London.

Catley, A., Alders, R.G., Wood, J.L., 2012. Participatory epidemiology: approaches, methods, experiences. The Veterinary Journal 191, 151-160.

Chatikobo, P., Choga, T., Ncube, C., Mutambara, J., 2013. Participatory diagnosis and prioritization of constraints to cattle production in some smallholder farming areas of Zimbabwe. Prev. Vet Med 109, 327-333.

Chenyambuga, S.W., Waiswa, C., Saimo, M., Ngumi, P., Gwakisa, P.S., 2010. Knowledge and perceptions of traditional livestock keepers on tick-borne diseases and sero-prevalence of Theileria parva around Lake Victoria Basin. Livestock research for rural development 22.

Chikerema, S.M., Matope, G., Pfukenyi, D.M., 2013. Awareness and attitude toward zoonoses with particular reference to anthrax among cattle owners in selected rural communities of Zimbabwe. Vector. Borne. Zoonotic. Dis. 13, 243-249.

Chikodzi, D., Zinhiva, H., Simba, F.M., Murwendo, T., 2013. Reclassification of Agro-ecological zones in Zimbabwe-The Rationale, Methods and Expected Benefits: The case of Masvingo Province. Journal of Sustainable Development in Africa 15.

De Clercq, E.M., Vanwambeke, S.O., Sungirai, M., Adehan, S., Lokossou, R., Madder, M., 2012. Geographic distribution of the invasive cattle tick Rhipicephalus microplus, a country-wide survey in Benin. Exp. Appl. Acarol. 58, 441-452.

De Garine-Wichatitsky, M., Miguel, E., Mukamuri, B., Garine-Wichatitsky, E., Wencelius, J., Pfukenyi, D.M., Caron, A., 2013. Coexisting with wildlife in transfrontier conservation areas in Zimbabwe: Cattle owners awareness of disease risks and perceptions of the role played by wildlife. Comparative immunology, microbiology and infectious diseases 36, 321-332.

Foil, L.D., Coleman, P., Eisler, M., Fragoso-Sanchez, H., Garcia-Vazquez, Z., Guerrero, F.D., Jonsson, N.N., Langstaff, I.G., Li, A.Y., Machila, N., Miller, R.J., Morton, J., Pruett, J.H., Torr, S., 2004. Factors that influence the prevalence of acaricide resistance and tick-borne diseases. Vet Parasitol 125, 163-181.

Hlatshwayo, M., Mbati, P.A., 2005. A survey of tick control methods used by resource-poor farmers in the Qwa-Qwa area of the eastern Free State Province, South Africa. Onderstepoort Journal of Veterinary Research 72, p-245.

IFAD, 2004. A participatory method to understand farmer perceptions of risk so as to improve the delivery, adoption and impact of East Coast fever controlA participatory method to understand farmer perceptions of risk so as to improve the delivery, adoption and impact of East Coast fever control. In: http://www.ifad.org/lrkm/tans/11.htm.

Jongejan, F., Uilenberg, G., 2004. The global importance of ticks. Parasitology 129 Suppl, S3-14.

Jonsson, N.N., 1997. Control of cattle ticks (Boophilus microplus) on Queensland dairy farms. Australian veterinary journal 75, 802-807. 
Jonsson, N.N., 2004. Integrated control programs for ticks on cattle: An: Examination of some possible components. FAO animal production and health paper. School of Veterinary Science, University of Queensland, Australia.

Katsande, T.C., More, S.J., Bock, R.E., Mabikacheche, L., Molloy, J.B., Ncube, C., 1999a. A serological survey of bovine babesiosis in northern and eastern Zimbabwe. Onderstepoort J Vet. Res. 66, 255-263.

Katsande, T.C., More, S.J., Bock, R.E., Mabikacheche, L., Molloy, J.B., Ncube, C., 1999b. A serological survey of bovine babesiosis in northern and eastern Zimbabwe. Onderstepoort $\mathbf{J}$ Vet Res. 66, 255-263.

Katsande, T.S., Mazhowu Turton, J.A., Munodzana, D., 1996. Babesia bovis case reports and the current distribution of Boophilus microplus in Zimbabwe. Zimbabwe Veterinary Journal 27, 33-36.

Latif, A.A., Hove, T., Kanhai, G.K., Masaka, S., Pegram, R.G., 2001. Epidemiological observations of Zimbabwean theileriosis: disease incidence and pathogenicity in susceptible cattle during Rhipicephalus appendiculatus nymphal and adult seasonal activity. Onderstepoort J Vet. Res. 68, 187-195.

Lempereur, L., Geysen, D., Madder, M., 2010. Development and validation of a PCR-RFLP test to identify African Rhipicephalus (Boophilus) ticks. Act. Trop. 114, 55-58.

Lynen, G., Zeman, P., Bakuname, C., Di, G.G., Mtui, P., Sanka, P., Jongejan, F., 2008. Shifts in the distributional ranges of Boophilus ticks in Tanzania: evidence that a parapatric boundary between Boophilus microplus and B. decoloratus follows climate gradients. Exp. Appl. Acarol. 44, 147-164.

Madder, M., Adehan, S., De Deken R., Adehan, R., Lokossou, R., 2012. New foci of Rhipicephalus microplus in West Africa. Exp. Appl. Acarol. 56, 385-390.

Madder, M., Thys, E., Achi, L., Toure, A., De Deken, R., 2010. Rhipicephalus (Boophilus) microplus: a most successful invasive tick species in West-Africa. Exp. Appl. Acarol. 53, 139-145.

Madder, M., Thys, E., Geysen, D., Baudoux, C., Horak, I., 2007. Boophilus microplus ticks found in West Africa. Exp. Appl. Acarol. 43, 233-234.

Mans, B.J., Gothe, R., Neitz, A.W.H., 2008. Tick toxins: perspectives on paralysis and other forms of toxicoses caused by ticks. Ticks: biology, disease and control, 108-126.

Mariner, J.C., Hendrickx, S., Pfeiffer, D.U., Costard, S., Knopf, L., Okuthe, S., Chibeu, D., Parmley, J., Musenero, M., Pisang, C., 2011. Integration of participatory approaches into surveillance systems. Revue Scientifique et Technique 30, 653-659.

Masika, P.J., Sonandi, A., Van Averbeke, W., 1997. Tick control by small-scale cattle farmers in the central Eastern Cape Province, South Africa. Journal of the South African Veterinary Association 68, p-45.

Mason, C.A., Norval, R.A.I., 1980. The ticks of Zimbabwe. I. The genus Boophilus. Zimbabwe Veterinary Journal 11, 36-43.

Mavedzenge, B.Z., Mehenehene, J., Murimbarimba, F., Scoones, I., 2006. Changes in the livestock sector in Zimbabwe following land reform: The case of Masvingo province. In. 
Minjauw, B., Mcleod, A., 2003. Tick Borne Diseases and Poverty: The Impact of ticks and tick borne diseases on the livelihood of small scale and marginal livestock owners in India and eastern and southern Africa. In: Department For International Development.

Minjauw, B., Muriuku, H.G., Romney, D., 2002. Development of the Farmer Field School Methodology for Smallholder Dairy Farmers in Kenya. In: Emerging Issues and Challenges.

Mosalagae, D., Pfukenyi, D.M., Matope, G., 2011. Milk producers' awareness of milk-borne zoonoses in selected smallholder and commercial dairy farms of Zimbabwe. Trop Anim Health Prod. 43, 733-739.

Moyo, B., Masika, P.J., 2009. Tick control methods used by resource-limited farmers and the effect of ticks on cattle in rural areas of the Eastern Cape Province, South Africa. Tropical animal health and production 41, 517-523.

Mugambi, J.M., Wesonga, F.D., Ndungu, S.G., 2012. Ticks and tick-borne disease control in a pastoral and an agro-pastoral farming systems in Kenya. Livestock research for rural development 24 .

Munyeme, M., Muma, J.B., Munang'andu, H.M., Kankya, C., Skjerve, E., Tryland, M., 2010. Cattle owners' awareness of bovine tuberculosis in high and low prevalence settings of the wildlifelivestock interface areas in Zambia. BMC Veterinary Research 6.

Mutibvu, T., Maburutse, B.E., Mbiriri, D.T., Kashangura, M.T., 2012. Constraints and opportunities for increased livestock production in communal areas: A case study of Simbe, Zimbabwe. Livestock research for rural development 24.

Ndhlovu, D.N., Makaya, P.V., Penzhorn, B.L., 2009. Tick infestation, and udder and teat damage in selected cattle herds of Matabeleland South, Zimbabwe. Onderstepoort J Vet Res 76, 235 248.

Norval, R.A., Fivaz, B.H., Lawrence, J.A., Brown, A.F., 1984a. Epidemiology of tick-borne diseases of cattle in Zimbabwe. II. Anaplasmosis. Trop Anim Health Prod. 16, 63-70.

Norval, R.A., Fivaz, B.H., Lawrence, J.A., Brown, A.F., 1984b. Epidemiology of tick-borne diseases of cattle in Zimbabwe. II. Anaplasmosis. Trop Anim Health Prod. 16, 63-70.

Nyangiwe, N., Harrison, A., Horak, I.G., 2013a. Displacement of Rhipicephalus decoloratus by Rhipicephalus microplus (Acari: Ixodidae) in the Eastern Cape Province, South Africa. Exp. Appl. Acarol.

Nyangiwe, N., Matthee, C., Horak, I., Matthee, S., 2013b. First record of the pantropical blue tick Rhipicephalus microplus in Namibia. Exp. Appl. Acarol. 61, 503-507.

Pegram, R.G., Tatchell, R.J., De Castro, J.J., Chizyuka, H.G.B., Creek, M.J., McCosker, P.J., Moran, M.C., Nigarura, G., 1993. Tick control: new concepts. World Anim Rev 74, 2-11.

Pegram, R.G., Wilson, D.D., Hansen, J.W., 2000. Past and present national tick control programs. Why they succeed or fail. Ann N. Y Acad. Sci 916, 546-554.

Peter, R.J., Van den Bossche, P., Penzhorn, B.L., Sharp, B., 2005. Tick, fly, and mosquito control lessons from the past, solutions for the future. Veterinary Parasitology 132, 205-215. 
Peter, T.F., Perry, B.D., O'Callaghan, C.J., Medley, G.F., Mlambo, G., Barbet, A.F., Mahan, S.M., 1999. Prevalence of Cowdria ruminantium infection in Amblyomma hebraeum ticks from heartwater-endemic areas of Zimbabwe. Epidemiol. Infect. 123, 309-316.

Peter, T.F., Perry, B.D., O'Callaghan, C.J., Medley, G.F., Shumba, W., Madzima, W., Burridge, M.J., Mahan, S.M., 1998. The distribution of heartwater in the highveld of Zimbabwe, 1980-1997. Onderstepoort J Vet. Res. 65, 177-187.

Pfukenyi, D.M., Chipunga, S.L., Dinginya, L., Matenga, E., 2010. A survey of pet ownership, awareness and public knowledge of pet zoonoses with particular reference to roundworms and hookworms in Harare, Zimbabwe. Trop Anim Health Prod. 42, 247-252.

Rikhotso, B.O., Stoltsz, W.H., Bryson, N.R., Sommerville, J.E., 2005. The impact of 2 dipping systems on endemic stability to bovine babesiosis and anaplasmosis in cattle in 4 communally grazed areas in Limpopo Province, South Africa. J S Afr Vet Assoc 76, 217-223.

Smeenk, I., Kelly, P.J., Wray, K., Musuka, G., Trees, A.J., Jongejan, F., 2000. Babesia bovis and B. bigemina DNA detected in cattle and ticks from Zimbabwe by polymerase chain reaction. J S. Afr. Vet Assoc. 71, 21-24.

Sungirai, M., Madder, M., Moyo, D.Z., De, C.P., Abatih, E.N., 2015. An update on the ecological distribution of the Ixodidae ticks in Zimbabwe. Exp. Appl. Acarol. 66, 269-280.

Tavirimirwa, B., Mwembe, R., Ngulube, B., Banana, N.Y.D., Nyamushamba, G.B., Ncube, S., Nkomboni, D., 2013. Communal cattle production in Zimbabwe: A review. Livestock research for rural development 25.

Tonnesen, M.H., Penzhorn, B.L., Bryson, N.R., Stoltsz, W.H., Masibigiri, T., 2004. Displacement of Boophilus decoloratus by Boophilus microplus in the Soutpansberg region, Limpopo Province, South Africa. Exp. Appl. Acarol. 32, 199-208.

Walker, A.R., Bouattour, A., Camicas, J.L., Estrada-Pena, A., Horak, I.G., Latif, A.A., Pegram, R.G., Preston, P.M., 2003. Ticks of domestic animals in Africa: a guide to identification of species. Bioscience reports Edinburgh.

Willadsen, P., 2006. Tick control: thoughts on a research agenda. Veterinary Parasitology 138, 161 168. 